\title{
Correction to: The multiple slope discontinuity beam element for nonlinear analysis of RC framed structures
}

\author{
Mohsen Rezaee Hajidehi • Antonino Spada - Giuseppe Giambanco
}

Published online: 1 February 2018

(C) Springer Science+Business Media B.V., part of Springer Nature 2018

\section{Correction to: Meccanica}

https://doi.org/10.1007/s11012-018-0817-3

This article has been published with an erroneous interpretation of the name of author Mohsen Rezaee
Hajidehi. Please find within this document the correct interpretation of the name of author Mohsen Rezaee Hajidehi that should be regarded by the reader as the final version. The original article has been corrected.

The original article can be found online at https://doi.org/10.1007/s11012-018-0817-3.

M. Rezaee Hajidehi · A. Spada ( $₫)$ · G. Giambanco

University of Palermo, Viale delle Scienze, Ed. 8,

Palermo, Italy

e-mail: antonino.spada@unipa.it

M. Rezaee Hajidehi

e-mail: mohsen.rezaeehajidehi@unipa.it

G. Giambanco

e-mail: giuseppe.giambanco@unipa.it 